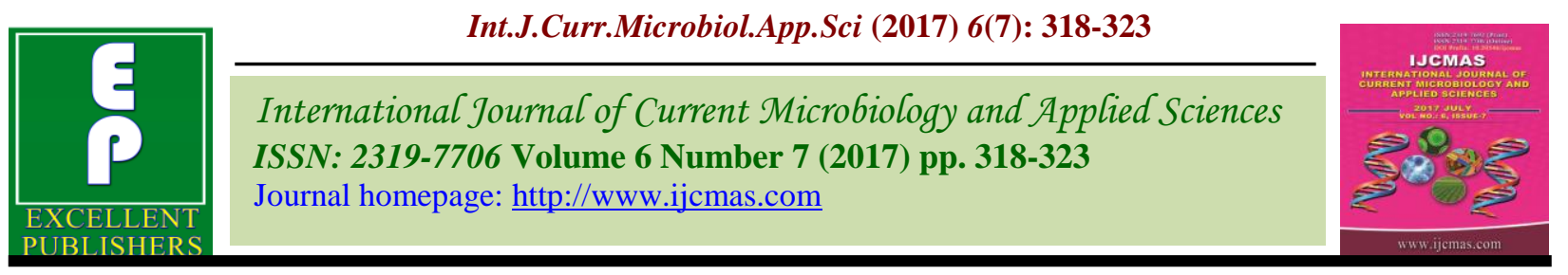

Original Research Article

https://doi.org/10.20546/ijcmas.2017.607.037

\title{
Effect of Different Seed Sources on Tamarind Kernel Powder and Seed Gum Yield
}

\author{
M. Sangareswari Nagajothi ${ }^{*}$, A. Balasubramanian ${ }^{1}$, Nandhkishore Thombare ${ }^{2}$ \\ and P.R. Renganayaki ${ }^{3}$ \\ ${ }^{1}$ Department of Silviculture, Ranchi, Uttrakhand, India \\ ${ }^{2}$ Indian Institute of Resins and Gums, Ranchi, Uttrakhand, India \\ ${ }^{3}$ Department of Tree Breeding, Forest College and Research Institute, Mettupalayam, \\ Coimbatore- Tamil Nadu -641301, India \\ *Corresponding author
}

\begin{tabular}{|c|c|}
\hline & A B S T R A C T \\
\hline Keywords & \multirow{4}{*}{$\begin{array}{l}\text { Tamarind seeds are rich source of polysaccharide which is obtained from } \\
\text { tamarind seed kernels. Present study was carried to examine the variation in } \\
\text { Tamarind Seed Powder (TSP) yield with respect to different seed sources } \\
\text { collected from Tamil Nadu (19), Kerala (3), Karnataka (13) and Andhra } \\
\text { Pradesh (5). } 100 \text { seed weight were measured and seeds were roasted and } \\
\text { Kernel and testa content and gum yield were measured. The maximum } 100 \\
\text { seed weight was obtained in Aasan and which also recorded in highest gum } \\
\text { yield. The percentage yield was about } 50 \% \text {. This study showed that the } \\
\text { seed source have great influence in gum yield. }\end{array}$} \\
\hline $\begin{array}{l}\text { Tamarind Gum, } \\
\text { Seed source, } 100 \\
\text { seed weight, Gum } \\
\text { yield, TSP. }\end{array}$ & \\
\hline Article Info & \\
\hline $\begin{array}{l}\text { Accepted: } \\
\text { 04 June } 2017 \\
\text { Available Online: } \\
\text { 10 July } 2017\end{array}$ & \\
\hline
\end{tabular}

\section{Introduction}

Tamarind seed is a by-product of the tamarind pulp industry. Tamarind seed consists of the seed coat or testa (20-30\%) and the kernel or endosperm (70-75\%) (Coronel, 1991; Shankaracharya, 1998). Tamarind seed is a typical underutilized material (Kumar \& Bhattacharya, 2008). Tamarind seed coat contains tannin, this presence of tannins and other dyeing matters in the seed testa make the whole seed unsuitable for consumption, but they become edible after removing seed testa by soaking in water and roasting. Tamarind seed is also used as raw material in the manufacture of polysaccharide (jellose), adhesive and tannin. Seeds and kernels are high in protein content, while the seed coat is rich in fibre and tannins (anti-nutritional factors). Seeds are gaining importance as an important source of natural polymer and as an alternative source of proteins, and are besides a good source of fatty acids and rich in some essential minerals, such as $\mathrm{Ca}, \mathrm{P}, \mathrm{Mg}$ and $\mathrm{K}$ (Caluwe, et al., 2010).

Tamarind kernel powder (TKP) has versatile applications in various industries hence, TKP being manufactured in large quantities. Textile and Jute industries are major consumer of Tamarind kernel Powder due to its good thickening properties uses this 
powder as textile thickeners while dyeing industry uses it for textile sizing. Many Other industries such as printing, jute, paper, explosives, plywood, mining, cosmetic, oil drilling, gas, tobacco and others also use tamarind kernel powder in different aspects. The product has various uses.

Consequently, TKP is used in cotton wraps, as soil stabilizer in mining industries and also for manufacturing of paints. Tamarind Kernel powder is rich in carbohydrates as well as protein. It is also used for producing adhesives.

The seeds are varies in variety of sizes and the polysaccharide content of the seeds differs in source wise. Hence, with this backdrop following study has been to taken to know the variation based on seed size and source.

\section{Materials and Methods}

The seeds from 44 sources were collected, cleaned, roasted and decorticated separately. The decorticated tamarind kernels were powdered using Pulverizer. The seeds were stored in clean and dried basket and utilized for all future research purposes.

\section{0 seed weight}

Determination of 100 seed weight was computed as described by ISTA (1996). The tamarind seeds (100 Nos.) were taken randomly from all sources separately were weighed in top pan balance and recorded in $\operatorname{gram}(\mathrm{g})$.

\section{Tamarind seed coat to kernel content}

Removal of testa from the seed is a difficult process, the testa was tenaciously held to the endosperms and it should be removed without damage to endosperm. The peeling of testa from the seeds was done by roasting of seeds at $110^{\circ} \mathrm{C}$ for 5 minutes and decortication process. The content of seed kernel to testa was estimated using method described by Doucette et al., (2001)

\section{Characterisation of tamarind kernel powder}

After the separation of seed coat from seed, the endosperm obtained was subjected for preparation of tamarind kernel powder. The decorticated endosperm was pulverised and tamarind kernel powder was prepared.

\section{Cold water soluble TSP preparation}

Weighed $20 \mathrm{~g}$ of tamarind Kernel powder and transfer it into $500 \mathrm{ml}$ Beaker and prepared slurry using $250 \mathrm{ml}$ of acetone. The beaker with aluminium foil was closed to avoid evaporation of acetone. This slurry was kept in magnetic stirrer for 12 hours to remove oil and fat contents in Tamarind kernel powder. After 12 hours of stirring filter the slurry using normal filter paper and take the filter paper and remove the filtrate in petri dish and dry it overnight. This filtered powder is free of oil and fat. Weigh $5 \mathrm{~g}$ of oil and fat free TKP powder and $100 \mathrm{ml}$ of distilled water. Slurry added into $400 \mathrm{ml}$ boiling water and boiled it for $20 \mathrm{~min}$ in $80^{\circ} \mathrm{c}$. After boiling, this solution was stirred for 2 hours by using magnetic stirrer. Centrifuge was done to remove the fibre and other residues from this slurry for $60 \mathrm{~min}$ at $5000-8000 \mathrm{rpm}$. The supernatant was extracted, poured into petri dishes and dried using freeze dryer. This method of cold water soluble TKP preparation is suggested by Nandhkishore which is unpublished method.

\section{Results and Discussion}

The seeds were roasted at $110^{\circ} \mathrm{C}$ for 5 minutes and roasted seeds were decorticated using tamarind seed decorticator. The weight of the kernel and testa were recorded in $100 \mathrm{~g}$ seeds. 
The decorticated seeds without seed coat were pulverized using Tamarind Seed Pulverizer and the yield of Tamarind Kernel Powder in $100 \mathrm{~g}$ Kernel was estimated. The source wise kernel weight, testa weight and tamarind kernel powder yield data were estimated.

\section{0 seed weight}

With respect to 100 seed weight, 40 seed sources varied between $95.9 \mathrm{~g}$ to 52.41 and Karnataka based seed source Aasan recorded with highest weight $(96.89 \mathrm{~g})$ followed by $\mathrm{TN}$ Arur $162(95.9 \mathrm{~g})$, TN Ariyalur (90.88g).

The minimum 100 seed weight was recorded in TN Kadambur. It is evident from table 1 (100 seed weight) in Tamarindus indica was recorded were vary with source.

These findings are in conformity with Pongamia pinnata wherein 100 seed weight has been reported in different Agro- Climatic zones of Southern Karnataka (Santhosh, 2007). Variability based on seed sources in 100 seed weight was observed in cluster bean by Mishra et al., 100 seed weight (1.5g -5.3 g).

\section{Kernel weight}

The seeds were roasted and seed coat was separated manually to record the seed testa and kernel ratio. The highest kernel weight was recorded in TN Ariyalur (82.13 g) succeed by Gundur (78.18 g) and TN Tuticorin (76.43 g). Even though, Aasan source recorded maximum 100 seed weight the kernel weight of $74.11 \mathrm{~g}$ was lowest.

Parameshwari and Srimathi (2009) have reported influence of seed source on recovery percentage on Tamarind of different AgroClimatic zones of Tamil Nadu. Which shows that seed weight and kernel weight is highly influenced by growing area in Tamarind seeds.

\section{Testa content}

The testa content is the negative factor for gum yield. The more amount of testa obviously leads to low content of kernel. The testa content was less in Arur (18.42) followed by Gundur.

\section{Kernel powder}

The roasted and decorticated seeds were powdered thorough pulverizer and the yield was recorded with respect $100 \mathrm{~g}$ kernel to powder. The kernel to powder ratio is depend on the pulverizer and mesh size. Hence, there was no significant difference recorded in 40 seed sources.

\section{Oil and fat free TKP}

Totally 40 sources from Tamil Nadu (19), Kerala (3), Karnataka (13) and Andhra Pradesh (5) were subjected to seed powder outturn and gum yield. Previously, the oil and fat free TKP were measured and obtained following results.

The highest oil and fat free TKP (13.91) was recorded in Aasan of Karnataka source which was followed by Uriham (12.94 g), Thenkanikottai $(12.77 \mathrm{~g})$. This results shows that oil content of tamarind kernel powder is significantly higher.

\section{Tamarind Seed Polysaccharide (TSP)}

The polysaccharide content of tamarind kernel powder is the major focus of this study. The Tamarind seed polysaccharide was significantly higher in all sources. It varied from $39 \%$ to $50.36 \%$ and Aasan recorded highest Polysaccharide content $50.36 \%$ with the value of $2.54 \mathrm{~g}$ in $5 \mathrm{~g}$ of Tamarind Kernel Powder followed by Gundur (2.39g), Dindigul $2.31 \mathrm{~g}$ which is about $48.72 \%$. 
Table.1 Effect of different seed sources on tamarind kernel powder and seed gum yield

\begin{tabular}{|c|c|c|c|c|c|c|c|}
\hline S.No. & Source & $\begin{array}{l}100 \text { seed } \\
\text { weight }\end{array}$ & $\begin{array}{c}\text { Kernel } \\
\text { weight } / 10 \\
0 \text { g seeds } \\
\end{array}$ & $\begin{array}{c}\text { Testa } \\
\text { weight } / 10 \\
\text { 0g seeds } \\
\end{array}$ & \multirow[t]{2}{*}{\begin{tabular}{|c|} 
Seed \\
powder in \\
$100 \mathrm{~g}$ kernel
\end{tabular}} & \multirow[t]{2}{*}{\begin{tabular}{|l}
$\begin{array}{l}\text { Oil and fat free } \\
\text { powder / (20g) }\end{array}$ \\
\end{tabular}} & \multirow[t]{2}{*}{ Gum yield / 5g } \\
\hline & \multicolumn{4}{|c|}{ TAMIL NADU SOURCE } & & & \\
\hline 1. & TN TUTICORIN & 73.66 & 76.52 & 23.31 & 97.50 & $\begin{array}{c}12.45 \\
(62.27)\end{array}$ & $\begin{array}{c}2.27 \\
(41.87)\end{array}$ \\
\hline 2. & TN ARIYALUR & 90.85 & 67.19 & 32.52 & 94.97 & $\begin{array}{c}11.18 \\
(55.92)\end{array}$ & $\begin{array}{c}2.34 \\
(40.80)\end{array}$ \\
\hline 3. & TN ARUR 162 & 95.64 & 82.33 & 18.42 & 94.43 & $\begin{array}{l}12.65 \\
(63.23)\end{array}$ & $\begin{array}{c}2.00 \\
(41.00)\end{array}$ \\
\hline 4. & TN COIMBATORE & 85.81 & 64.00 & 32.36 & 94.46 & $\begin{array}{c}12.89 \\
(64.47)\end{array}$ & $\begin{array}{c}2.13 \\
(46.73)\end{array}$ \\
\hline 5. & TN DHARMAPURI & 78.00 & 63.26 & 36.42 & 98.03 & $\begin{array}{c}11.17 \\
(55.83)\end{array}$ & $\begin{array}{c}2.14 \\
(43.13)\end{array}$ \\
\hline 6. & TN DINDIGUL & 66.81 & 67.50 & 72.54 & 97.48 & $\begin{array}{l}12.60 \\
(63.02)\end{array}$ & $\begin{array}{c}2.31 \\
(48.27)\end{array}$ \\
\hline 7. & TN KRISHNAGIRI & 72.16 & 65.38 & 34.45 & 94.64 & $\begin{array}{c}10.27 \\
(51.35)\end{array}$ & $\begin{array}{c}2.08 \\
(42.60)\end{array}$ \\
\hline 8. & TN MADURAI & 72.40 & 68.30 & 31.99 & 98.05 & $\begin{array}{l}12.15 \\
(60.77) \\
\end{array}$ & $\begin{array}{c}2.05 \\
(40.93) \\
\end{array}$ \\
\hline 9. & TN PERAMBALUR & 86.29 & 68.42 & 31.75 & 98.96 & $\begin{array}{c}11.61 \\
(58.05)\end{array}$ & $\begin{array}{c}2.03 \\
(40.60) \\
\end{array}$ \\
\hline 10 & TN POLLACHI & 77.64 & 67.25 & 32.46 & 97.03 & $\begin{array}{c}12.52 \\
(62.58)\end{array}$ & $\begin{array}{c}2.05 \\
(40.93) \\
\end{array}$ \\
\hline 11 & TN SALEM & 87.20 & 68.99 & 31.04 & 96.06 & $\begin{array}{c}11.54 \\
(57.68)\end{array}$ & $\begin{array}{c}2.31 \\
(47.07)\end{array}$ \\
\hline 12 & TN THENKANIKOTTAI & 71.23 & 65.44 & 33.56 & 98.82 & $\begin{array}{c}12.42 \\
(62.08)\end{array}$ & $\begin{array}{c}2.11 \\
(41.87)\end{array}$ \\
\hline 13 & TN HASANUR 9 & 71.61 & 70.45 & 29.38 & 97.78 & $\begin{array}{c}11.21 \\
(56.07)\end{array}$ & $\begin{array}{c}2.31 \\
(45.00) \\
\end{array}$ \\
\hline 14 & TN ARUR 110 & 73.77 & 67.63 & 33.12 & 96.25 & $\begin{array}{c}12.51 \\
(62.57) \\
\end{array}$ & $\begin{array}{c}2.03 \\
(40.53) \\
\end{array}$ \\
\hline 15 & $\begin{array}{c}\text { TN } \\
\text { GOPICHETTIPALAYAM }\end{array}$ & 59.65 & 68.24 & 31.66 & 95.56 & $\begin{array}{c}12.49 \\
(62.43)\end{array}$ & $\begin{array}{c}2.06 \\
(42.13) \\
\end{array}$ \\
\hline 16 & TN URIHAM 112 & 68.67 & 69.02 & 30.50 & 98.04 & $\begin{array}{c}12.30 \\
(61.48)\end{array}$ & $\begin{array}{c}1.98 \\
(39.33)\end{array}$ \\
\hline 17 & TN VELLORE 29 & 80.19 & 70.25 & 28.34 & 97.76 & $\begin{array}{c}12.51 \\
(62.55)\end{array}$ & $\begin{array}{c}2.25 \\
(44.47)\end{array}$ \\
\hline 18 & TN VELLORE & 69.74 & 67.24 & 32.43 & 95.03 & $\begin{array}{c}12.29 \\
(61.45)\end{array}$ & $\begin{array}{c}2.01 \\
(39.93)\end{array}$ \\
\hline 19 & TN KADAMPUR & 52.30 & 70.48 & 29.17 & 97.03 & $\begin{array}{l}12.33 \\
(61.67)\end{array}$ & $\begin{array}{c}2.30 \\
(45.00)\end{array}$ \\
\hline II & \multicolumn{4}{|l|}{ KERALA SOURCE } & & & \\
\hline 20. & PATHARI & 67.55 & 67.46 & 32.34 & 97.88 & $\begin{array}{c}12.42 \\
(62.08) \\
\end{array}$ & $\begin{array}{c}2.26 \\
(43.93) \\
\end{array}$ \\
\hline 21 & VELANTHAVALEM & 78.34 & 64.43 & 35.50 & 95.34 & $\begin{array}{c}11.45 \\
(57.25) \\
\end{array}$ & $\begin{array}{c}2.25 \\
(43.40) \\
\end{array}$ \\
\hline 22. & PALAKKAD & 74.92 & 68.28 & 29.92 & 95.83 & $\begin{array}{c}12.29 \\
(61.45)\end{array}$ & $\begin{array}{c}2.21 \\
(38.47) \\
\end{array}$ \\
\hline III & \multicolumn{7}{|c|}{ ANDHRA PRADESH SOURCE } \\
\hline
\end{tabular}




\begin{tabular}{|c|c|c|c|c|c|c|c|}
\hline 23. & GUNDUR & 89.57 & 78.52 & 21.34 & 97.13 & $\begin{array}{c}11.76 \\
(58.78)\end{array}$ & $\begin{array}{c}2.39 \\
(48.00)\end{array}$ \\
\hline 24 & HOSUR & 75.50 & 65.32 & 34.12 & 98.19 & $\begin{array}{c}10.57 \\
(52.83)\end{array}$ & $\begin{array}{c}2.09 \\
(41.20)\end{array}$ \\
\hline 25. & NELLORE & 78.18 & 65.16 & 34.38 & 98.76 & $\begin{array}{c}11.43 \\
(57.15)\end{array}$ & $\begin{array}{c}2.27 \\
(45.13)\end{array}$ \\
\hline 26. & BANGADUPETTY & 76.57 & 66.59 & 32.82 & 94.05 & $\begin{array}{c}12.32 \\
(61.62)\end{array}$ & $\begin{array}{c}2.23 \\
(43.73)\end{array}$ \\
\hline 27. & TIRUPATHI & 69.58 & 65.38 & 34.49 & 97.13 & $\begin{array}{c}10.91 \\
(54.57)\end{array}$ & $\begin{array}{c}2.25 \\
(44.53)\end{array}$ \\
\hline IV & \multicolumn{7}{|c|}{ KARANATAKA SOURCE } \\
\hline 28. & NOKKANUR & 65.38 & 70.37 & 29.37 & 98.35 & $\begin{array}{c}10.03 \\
(50.13)\end{array}$ & $\begin{array}{c}1.98 \\
(38.73)\end{array}$ \\
\hline 29 & SORRANKARAI & 70.37 & 60.70 & 38.96 & 93.18 & $\begin{array}{c}11.41 \\
(57.05)\end{array}$ & $\begin{array}{c}2.06 \\
(40.40)\end{array}$ \\
\hline 30 & AASAN & 60.70 & 74.33 & 26.69 & 96.12 & $\begin{array}{c}12.33 \\
(61.67)\end{array}$ & $\begin{array}{c}2.54 \\
(50.60)\end{array}$ \\
\hline 31 & ANADAPUR & 74.33 & 64.80 & 35.66 & 94.15 & $\begin{array}{c}13.91 \\
(69.55)\end{array}$ & $\begin{array}{c}2.34 \\
(47.07)\end{array}$ \\
\hline 32 & GUNDELPET & 64.80 & 68.61 & 31.66 & 97.13 & $\begin{array}{c}11.91 \\
(59.53)\end{array}$ & $\begin{array}{c}2.04 \\
(41.13)\end{array}$ \\
\hline 33 & IRRIYUR & 68.61 & 65.58 & 34.39 & 97.67 & $\begin{array}{c}11.38 \\
(56.88)\end{array}$ & $\begin{array}{c}2.31 \\
(47.33)\end{array}$ \\
\hline 34 & KOLLEGAL & 65.58 & 61.45 & 38.61 & 96.0 & $\begin{array}{c}10.54 \\
(52.70)\end{array}$ & $\begin{array}{c}2.13 \\
(46.20)\end{array}$ \\
\hline 35 & THUMKUR & 61.45 & 64.63 & 34.42 & 98.05 & $\begin{array}{c}12.13 \\
(60.67)\end{array}$ & $\begin{array}{c}2.01 \\
(40.13)\end{array}$ \\
\hline 36 & PARAMBIKULAM & 64.63 & 60.35 & 39.17 & 96.87 & $\begin{array}{c}12.56 \\
(62.78)\end{array}$ & $\begin{array}{c}2.16 \\
(43.47)\end{array}$ \\
\hline 37 & CHITRADURGA & 60.35 & 65.31 & 35.57 & 95.95 & $\begin{array}{c}12.67 \\
(63.37)\end{array}$ & $\begin{array}{c}2.07 \\
(41.13)\end{array}$ \\
\hline 38 & UDAYARPALAM & 65.31 & 70.47 & 29.49 & 97.67 & $\begin{array}{c}11.33 \\
(56.65)\end{array}$ & $\begin{array}{c}2.31 \\
(46.27)\end{array}$ \\
\hline 39 & UMLI & 70.47 & 71.36 & 28.76 & 97.14 & $\begin{array}{c}11.63 \\
(58.15)\end{array}$ & $\begin{array}{c}2.21 \\
(45.00)\end{array}$ \\
\hline 40 & HP KOTTAI & 71.36 & 69.09 & 32.95 & 95.14 & $\begin{array}{c}10.71 \\
(53.55)\end{array}$ & $\begin{array}{c}2.06 \\
(41.07) \\
\end{array}$ \\
\hline & Mean & 67.90 & 67.90 & 32.90 & 96.75 & 11.87 & 2.13 \\
\hline & SEd & 0.2077 & 0.5336 & 0.3402 & & 0.2447 & 0.0698 \\
\hline & CD (0.05) & 0.4134 & 1.0620 & 0.6771 & & 0.4870 & 0.1389 \\
\hline
\end{tabular}

The lowest amount of TSP found in Nokkanur $(1.98 \mathrm{~g})$ preceeded by Thumkur and Vellore $(2.01 \mathrm{~g})$. The maximum 100 seed weight was not influenced on kernel weight and seed gum yield which shows that kernel weight and gum yield is not directly related.

Highest percentage of gum yield was obtained from seed sources were mostly dry tracts. It shows that tamarind kernel powder contains about $50 \%$ of starch which is known as polysaccharide. Similarly, wide variation in different biochemical parameters of cluster bean seed endosperm (30.4-46.3\%) and gum content reported in Pathak et al., 2011.

In conclusion owing to the wide demand for Tamarind kernel powder and their value addition, present study shows that seed from different sources possess variation in 100 seed 
weight, kernel content and testa content. The seeds from Aasan can be utilized for maximum gum out turn and other sources can utilized for tamarind kernel powder production.

\section{Acknowledgement}

This is a part of the Ph.D. (Forestry) thesis submitted by M. Sangareswari Nagajothi, to the Department of Silviculture, Forest College and Research Institute Tamil Nadu Agricultural University, Coimbatore. I kindly acknowledge Indian Institute of Resins and Gums (IINRG) for providing the facilities to carry out my research work.

\section{References}

E. De caluwe, K. Halamova, P. Van Damme (2010), Tamarindus indica L. - A review of traditional uses, phytochemistry and pharmacology: Afrika focus - Volume 23, Nr. 1

El-Siddig, K., Gunasena, H.P.M., Prasa, B.A., Pushpakumara, D.K.N.G., Ramana, K.V.R., Vijayanand. P., Williams, J.T. (2006). Tamarind - Tamarindus indica L. Fruits for the future 1. Southampton Centre for Underutilized Crops, Southampton, UK, 188p.

ISTA (International seed testing association). 1996. A guide for seed testing: An overview. Pp: 12-18.
Kumar V (1997), 'Tamarind Seed - A Valuable Source of Commercial Pectin'. Proc. Nat. Sym. on Tamarindus indica L, Tirupathi (A.P.), organized by Forest Dept. of A.P, India, 27-28 June, 1997, pp. 192-7.

Mishra SK, Singh N, Sharma SK (2009) Status and utilization of genetic resources of arid legumes in India. In: Kumar D, Henry A (Eds) Perspective research activities of arid legumes in India. Indian Arid Legumes Society, CAZRI, Jodhpur, pp 23-30

Parameshwari, K and Srimathi, P.2009. Influence of seed source variation on size grades of Tamarind (Tamarindus indica Linn). International Journal of legume Research 4:240-244.

Pathak R, Singh M, Henry A (2011a) Stability, correlation and path analysis for seed yield and yield attributing traits in clusterbean. Indian $\mathbf{J}$ Agric Sci 81(4):309-313

Shankaracharya N B (1998), 'Tamarind Chemistry, Technology and Uses - a critical appraisal,' Jour. Food Technol, 35(3), 193-208.

Santhosh Kumar, M.S. 2007. Provenance studies in Pongamia pinnata in different Agro- climatic zones of Southern Karnataka. M.Sc (Forestry) Thesis submitted to University of Agricultural Sciences, Dharwad: 45-47.

\section{How to cite this article:}

Sangareswari Nagajothi, M., A. Balasubramanian, Nandhkishore Thombare and Renganayaki, P.R. 2017. Effect of Different Seed Sources on Tamarind Kernel Powder and Seed Gum Yield. Int.J.Curr.Microbiol.App.Sci. 6(7): 318-323. doi: https://doi.org/10.20546/ijcmas.2017.607.037 